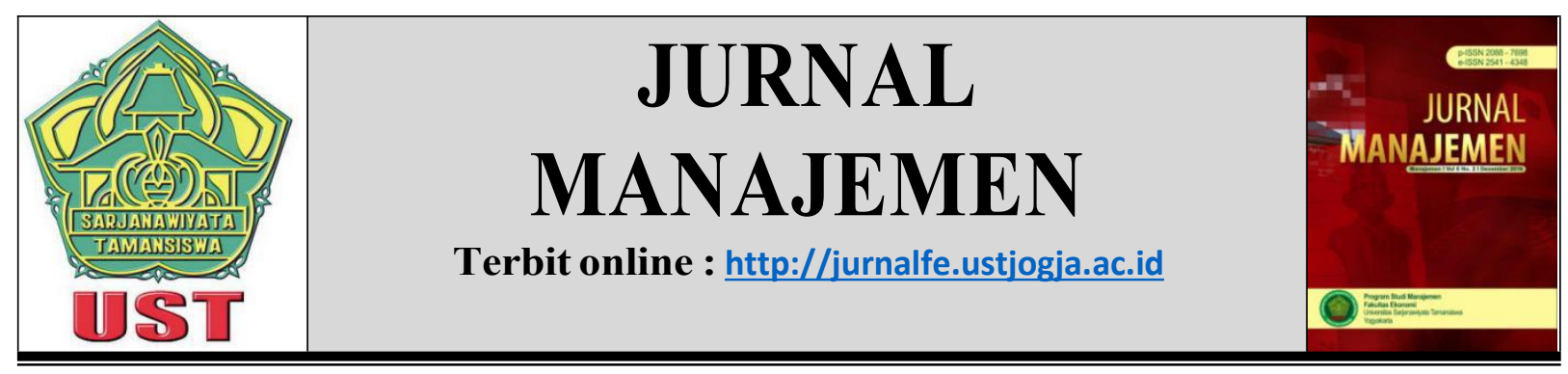

\title{
ANALISIS ENTRY DAN EXIT MENGGUNAKAN SIMPLE MOVING AVERAGE DAN STOCHASTIC OSCILLATOR PADA EMITEN UNVR
}

\author{
Arnanda Ajisaputra \\ Program Studi Manajemen Sekolah Tinggi Ilmu Ekonomi Indocakti Malang \\ Email: paranggaruda@gmail.com
}

\begin{tabular}{ll}
\hline Informasi Naskah & \multicolumn{1}{c}{ Abstrak } \\
\hline $\begin{array}{l}\text { Diterima: 20 Mei 2019 } \\
\text { Revisi: } 25 \text { November }\end{array}$ & This study aims to analyze the right time to enter and exit PT. \\
$\mathbf{2 0 1 9}$ & Unilever Indonesia, tbk (UNVR) uses a combination of Stochastic \\
Terbit: 18 Desember & Oscillator and Simple Moving Average (SMA) indicators. The \\
$\mathbf{2 0 1 9}$ & research method used is descriptive qualitative with four \\
\hline Kata Kunci: Stochastic & instruments, namely: candlestick graph, trendline; Simple Moving \\
Oscillator, simple moving & Average (SMA); and Stochastic Oscillator. Analysis of the data \\
average, entry, exit & used is data reduction, data exposure, and data verification. The \\
& results showed that the ideal time for traders to make the best \\
& investment trading is between June 2, 2017 until June 21, 2018 by \\
& producing nine entry and exit recommendations, out of the nine \\
& recommendations there are eight recommendations reached for \\
& the exit target and two recommendations have not yet been \\
& reached.
\end{tabular}

\section{PENDAHULUAN}

PT Unilever Indonesia.Tbk merupakan sebuah perusahaan raksasa yang bergerak di bidang produksi barang kebutuhan rumah tangga. Berawal pada tahun 1890-an, William Hesketh Lever pendiri Lever Brother mulai memunculkan sebuah ide tertulis tentang Sabun Sunlight yang diperuntukkan guna membantu para wanita dalam mengerjakan tugas-tugas mereka di istana maupun di rumah-rumah para pembesar dan pemodal di wilayah kerajaan Victoria. Pada tahun 1885 produk William yang telah terbukti kehandalannya merambah luas ke wilayah-wilayah negara tetangga dan menyentuh pada level masyarakat menengah ke bawah (Anonim, 2018).

Pada 5 Desember 1933 PT Unilever mulai merambah ke Indonesia dengan Visi "Untuk Meraih Rasa Cinta dan Penghargaan dari Indonesia dengan Menyentuh Kehidupan Setiap Orang Indonesia Setiap Harinya" (Anonim, 2018). PT Unilever mulai terdaftar di Bursa Efek Jakarta pada tahun 1982 dengan kode emiten UNVR. Harga Initial Public Offering (IPO) tercatat Rp 3.175 per lembar (Chandra, 2017). Kini UNVR tercatat sebagai emiten yang memiliki kapitalisasi besar dan diperdagangkan secara aktif di Bursa Efek Indonesia. 
Kapitalisasi yang besar pada UNVR ditopang oleh kondisi fundamental yang sangat baik. Selama Bulan Januari s.d Maret 2018 UNVR telah mendapatkan penjualan bersih senilai $\mathrm{Rp}$ 10,74 Triliun dan telah mendapatkan laba bersih senilai $\mathrm{Rp}$ 1,84 Triliun per akhir Maret 2018. Sedangkan jumlah aset yang dimiliki UNVR per tanggal 31 Maret 2018 sebesar Rp 20,24 Triliun dan mendapatkan catatan kenaikan sebesar 7,06\% YoY dari sebelumnya sebesar Rp 18,9 Triliun. Sedangkan jumlah liabilitas dan ekuitas UNVR senilai Rp 13,23 Triliun dan Rp 7,01 Triliun (Noviani, 2018).

Dari kondisi fundamental tersebut UNVR juga termasuk salah satu emiten yang dikategorikan sebagai saham Blue Chip. Menurut Tjiptono \& Fakhrudin (2012) Saham Blue Chip atau biasa disebut saham unggulan merupakan saham yang diperdagangkan di pasar bursa secara terbuka dengan reputasi fundamental dan teknikal yang tinggi serta memiliki pendapatan yang cukup stabil dalam periodenya. Selain itu saham ini juga konsisten dan kontinyu dalam memberikan deviden kapada para investornya.

Ong (2011) menambahkan, suatu emiten saham belum dapat dikatakan sebagai blue chip stock apabila emiten tersebut hanya kuat di fundamentalnya, namun lemah ditinjau dari teknikalnya. Secara teknikal selama periode Simple Moving Average (SMA) 100 di atas SMA 200 antara tahun 2017 dan tahun 2018 yang terjadi selama Bulan Juni 2017 hingga Bulan Juni 2018, UNVR diperdagangkan dengan harga tertinggi Rp 58.100 dan harga terendah mencapai $\mathrm{Rp}$ 43.875. Selama itu pula major trend terlihat naik dan turun dengan secondary trend yang sangat aktif terbentuk sebagaimana gelombang (id.investing.com, 2018). Ditinjau dari indikator Stochastic Oscillator UNVR juga nampak sebagai emiten yang aktif diperdagangkan dengan kondisi permintaan dan penawaran yang wajar.

Emiten yang aktif diperdagangkan di pasar bursa tentu mengalami perubahan harga yang fluktuatif. Perubahan harga UNVR yang sangat fluktuatif di pasar bursa mungkin tidak menjadi masalah bagi investor bertipe unsystematic based market yang profit investasinya berdasarkan deviden, mereka hanya perlu melihat kondisi fundamental UNVR tanpa melihat pergerakan harga pasar. Pergerakan harga yang fluktuatif pada UNVR dirasa sebagai masalah oleh para investor bertipe systematic based market, baik itu Trader yang mengharapkan profit secara kombinasi antara deviden maupun capital gain maupun Trader murni yang hanya mengharapkan profit investasi melalui capital gain saja. Permasalahan utama yang dihadapi para Trader khususnya bagi pemula adalah melakukan entry dan exit yang salah, sehingga mereka gagal dalam mendapatkan profit maksimal bahkan mengalami kerugian.

Untuk memaksimalkan profit atau meminimalisir kerugian para Trader terhadap permasalahan fluktuasi harga pada saham-saham blue chip semisal UNVR, diperlukan analisis dan metode yang tepat untuk memberikan sinyal bagi para Trader dalam melakukan entry dan exit di waktu yang tepat pula. Dari beberapa analisis teknikal yang diperlukan Trader untuk menentukan waktu buy maupun sell paling mudah dan akurat adalah menggunakan indikator Stochastic Oscillator yang bersifat leading atau Simple Moving Average (SMA) yang bersifat lagging. Biasanya para analis maupun Trader menggunakan kedua indikator tersebut secara terpisah, guna menambah keakuratan hasil analisis maka peneliti mencoba untuk menggabungkan kedua indikator tersebut dalam menganalisis ketepatan dan kecepatan target dari entry menuju exit dengan prosentase maksimal yang ditentukan berdasarkan penelitian terdahulu pada saham UNVR yaitu senilai positif $300 \%$ dari range. Dengan kedua indikator tersebut diharapkan dapat memunculkan rekomendasi entry dan exit untuk mencapai profit maksimal bagi ara Trader UNVR. 


\section{KAJIAN PUSTAKA}

Analisis Teknikal

Secara tekstual analisis teknikal merupakan salah satu metode evaluasi terhadap pergerakan harga sebuah emiten saham di pasar bursa (Vibby, 2008). Pergerakan harga yang ditimbulkan oleh demand dan supply dalam satu hari perdagangan direkam dalam satu catatan berupa grafik. Grafik-grafik yang disusun dalam satu periode tertentu membentuk sebuah tren yang dapat dibaca, dianalisis, dan diprediksi.

Analisis teknikal didasarkan pada Teori Dow, yang memiliki tiga prinsip utama (Murphy, 1999), yaitu: (1) market price discount everything, memberikan makna bahwa apa yang terjadi di pasar menggambarkan semua tentang faktor-faktor yang mempengaruhinya.; (2) price moves in trend, menjelaskan bahwa harga selalu bergerak mengikuti jalurnya, jalur ini disebut sebagai tren. Tren dapat dianalisis dengan metode trendline dan indikator sehingga dapat diketahui kemanakah tren akan terbentuk; (3) history repeat itself, sejarah akan berulang, hanya warna dan dan kualitasnya yang berbeda. Sama dengan apa yang terjadi pada tren di pasar bursa, suatu saat tren yang telah terjadi akan terbentuk serupa di masa mendatang hanya kekuatan dan harganya yang berbeda. Atas dasar itulah banyak Trader dan analis menggunakan analisis teknikal untuk menggambarkan kondisi pasar di masa lalu sebagai bahan prediksi mereka dalam menentukan strategi entry dan exit, karena tren masa lalu akan memberikan gambaran bagaimana terbentuknya tren masa mendatang.

Trend masa lalu dapat dianalisa dan dideskripsikan setelah menarik garis tren, walau demikian garis tren tidak dapat memprediksi besarnya momentum (kekuatan) pergerakan harga yang akan terjadi. Garis tren tidak pula dapat memprediksi berapa harga yang akan terbentuk dari tren maksimum yang akan dicapai dan harga yang akan terbentuk dari tren minimum yang akan dicapai. Guna memprediksi momentum pergerakan harga yang akan terbentuk digunakan sebuah indikator momentum serta indikator rata-rata perubahan harga.

Beberapa indikator momentum yang dapat digunakan adalah: Stochastic Oscillator, Moving Average Divergent-Convergent (MACD), dan Relative Strength Index (RSI), sedangkan indikator perubahan harga dapat menggunakan Moving Average (MA) yang dibagi menjadi tiga, yaitu: (1) Simple Moving Average (SMA); (2) Weighted Moving Average (WMA); dan (3) Exponential Moving Average (EMA).

\section{Indikator Stochastic Oscillator}

Indikator Stocastic Oscillator dicetuskan oleh George C Land pada akhir tahun 1950-an. Indikator yang memiliki skala 0 s.d 100 ini digunakan sebagai alat untuk mengukur posisi closing terhadap selisih antara high dan low pada waktu tertentu dengan rumusan sebagai berikut (Syamsir, 2004).

$$
\begin{aligned}
& \text { Gambar 1. Rumus Indikator Stochastic Oscillator } \\
& \qquad \% K=\left(\frac{\operatorname{Re} \text { centclose }- \text { LowestLow }}{\text { HighestHigh }- \text { Lowestlow }}\right) \times 100
\end{aligned}
$$

Sumber: Syamsir, 2004

Indikator ini terdiri atas dua garis utama yaitu \%K dan \%D. Menurut Mangkulo (2014) indikator utama yang terbentuk adalah $\% \mathrm{~K}$, sedangkan $\% \mathrm{D}$ merupakan SMA dari $\% \mathrm{~K}$ itu sendiri, sehingga $\% \mathrm{D}$ digunakan untuk mengevaluasi gerak $\% \mathrm{~K}$ dalam menentukan kekuatan relatif perdagangan terhadap posisi di market dalam periode tertentu.

Apabila $\% \mathrm{~K}$ bersinggungan di atas skala 80 , hal ini mengindikasikan adanya keadaan jenuh beli yang disebut sebagai over bought (Wira, 2014). Apabila Trader melihat adanya kondisi over bought, hendaknya dilakukan penjualan terhadap emiten yang dimilikinya karena 
diasumsikan harga suatu emiten di pasar bursa akan mengalami penurunan di keesokan harinya hingga jangka waktu tertentu. Keadaan inilah yang dinamakan oleh para Trader sebagai Death Cross, karena para Trader sudah tidak dapat lagi menjual dengan harga yang lebih tinggi atau harga sudah benar-benar jenuh untuk terus bergerak ke atas (Ong, 2011).

Begitu pula apabila \%K bersinggungan di bawah skala 20 akan terjadi jenuh jual (over sold). Menurut Ong (2011) Trader secara ideal dapat melakukan pembelian emiten atau memulai investasinya. Kondisi ini seringkali diistilahkan oleh para Trader sebagai Golden Cross sebab kondisi tersebut merupakan peluang emas bagi Trader untuk melakukan investasi dan mengharap profit di waktu mendatang saat terjadi death cross.

\section{Moving Average (MA)}

MA merupakan sebuah indikator yang menampilkan sebuah nilai rerata dari harga yang terbentuk di pasar bursa dalam periode tertentu. Menurut Burns \& Burns (2015), MA merupakan indikator yang ditempatkan langsung pada grafik dengan fungsi sebagai alat identifikasi tren yang sangat penting bagi para analis maupun Trader untuk menentukan exit dan entry secara akurat. Menurut Burns \& Burns (2015) untuk meningkatkan akurasi entry dan exit tidak cukup hanya mengandalkan MA saja, namun indikator ini dapat digabungkan dengan indikator yang yang lain seperti Stochastic Oscillator, MACD, maupun RSI.

Menurut Droke (2001), MA dibagi menjadi menjadi tiga yaitu: Simple Mocing Average (SMA), Weighted Moving Average (WMA), dan Exponential Moving Average (EMA). Ketiganya sama metodologi dan fungsinya namun berbeda dalam pembobotannya. Semakin kompleks pembobotannya maka semakin akurat dalam memprediksi harga namun semakin banyak false signal yang dihasilkan dalam memprediksi dimulainya sebuah arah pembalikan tren (reversal trend).

Menurut Ong (2011), Trader yang memiliki tipe the safety Trader lebih tepat bila menggunakan analisis SMA karena false signal yang muncul dari arah pembalikan tren lebih akurat walaupun harga yang sedikit meleset tidak begitu berpengaruh untuk ditarget. Sedangkan apabila Trader memiliki tipe the risk Trader, maka yang labih baik adalah menggunakan EMA lebih akurat dalam menganalisis harga yang terbentuk daripada tren yang terjadi dan hal ini bermanfaat bagi the risk Traders.

\section{Peran SMA dan Stocastic Oscillator dalam Memberikan Sinyal Beli dan Jual}

Sesuai dengan peran dan fungsinya, SMA memberikan sinyal terhadap pergerakan harga selama periode tertentu yang ditentukan. Sebagai contoh SMA 100 dan SMA 200, maka SMA 100 menunjukkan rata-rata pergerakan harga selama seratus hari, sedangkan SMA 200 menunjukkan rata-rata pergerakan harga selama 200 hari.

Menurut Gencay \& Stengos (1998) SMA 50 dan SMA 20 sering digunakan oleh para Trader dan analis untuk menentukan entry dan exit saham mereka, namun keakuratan keduanya masih perlu ditingkatkan menjadi WMA atau EMA, sedangkan apabila tetap menggunakan SMA hendaknya memilih SMA 100 dan SMA 200. Secara logika apabila SMA 100 di atas SMA 200 maka pergerakan harga saham cukup aktif di pasar, begitu pula sebaliknya.

Zhu \& Zhou (2009) menjelaskan lebih rinci tentang waktu yang tepat untuk melakukan entry yaitu apabila SMA 100 dan SMA 200 bertemu, dimana SMA 100 memotong SMA 200 dari bawah, inilah yang dinamakan golden cross dan inilah waktu yang tepat untuk melakukan entry. Sedangkan apabila SMA 100 memotong SMA 200 dari atas dimana kondisi tersebut dinamakan death cross, maka hendaknya Traders melakukan exit atas sahamnya.

Pernyataan Zhu \& Zhou (2009) memang cukup efektif untuk mendulang keuntungan 
yang maksimal sebagaimana dikuatkan oleh Ong (2011), namun ternyata tidak selamanya melakukan entry pada saat SMA golden cross efisien, bisa jadi memerlukan waktu yang cukup lama untuk sampai ke waktu SMA golden death terbentuk. Apabila SMA 100 bertemu SMA 200 di golden cross dapat terulang kembali di golden death sekira satu hingga dua bulan atau lebih tergantung perubahan harga yang terjadi dan tingginya tingkat bid and over, namun jarang ada yang terbentuk di antara keduanya kurang dari 2 pekan (Bessembinder \& Chan, 1998).

Indikator kedua yang sering digunakan Trader dan analis untuk menganalisis pergerakan harga dan menentukan entry dan exit adalah Stocastic Oscillator, indikator ini memiliki range 0 s.d. 100. Menurut Rosillo dkk (2013) Stocastic Oscillator mampu mengetahui tingkat kejenuhan pasar sekaligus memberikan sinyal yang baik untuk entry maupun exit. Garis merah yang perlu diperhatikan adalah nilai 20 dan 80, wilayah di bawah nilai 20 disebut wilayah overbought sedangkan wilayah di atas 80 disebut overshold.

Menurut Ong (2011) dan Shen \& Loh (2004), apabila \%K memotong \%D di wilayah overbought disebut sebagai golden cross, saat kedua garis tersebut berpotongan merupakan saat yang paling tepat untuk entry. Sebaliknya apabila $\% \mathrm{~K}$ memotong $\% \mathrm{D}$ di wilayah overshold, hal ini disebut death cross dan saat yang paling tepat untuk melakukan exit.

Traders dan analis biasa menggunakan Stocastic Oscillator secara terpisah dengan metode SMA, karena sifat keduanya yang berbeda antara leading dan legging (Ong, 2011), namun hal ini dirasa rancu karena terdapat penelitian yang menyatukan antara kedua sifat tersebut dan menghasilkan deskripsi serta prediksi market yang akurat. Rosillo dkk (2013) menguji antara RSI, MACD, Momentum dan Stocastic Oscillator yang kesemuanya merupakan gabungan dari grafik analisis pergerakan harga di pasar dengan kedua sifat dan dihasilkan prediksi yang tepat apabila menggabungkan keempatnya.

\section{METODE PENELITIAN}

Bahan penelitian ini adalah emiten UNVR yang akan dianalisis untuk dideskripsikan pergerakan pasarnya kemudian dianalisis lebih lanjut untuk mengetahui titik entry (buy efektif) dan exit (sell efektif) sebagai bahan evaluasi Traders dalam meraih profit maksimalnya dan bahan penelitian lanjutan bagi yang akan melakukan penelitian prediktif.

Waktu penelitian didasarkan atas data penelitian yang diambil secara flasback selama satu tahun mulai dari tanggal 2 Juni 2017 sampai dengan 21 Juni 2018. Pertimbangan pengambilan data selama rentang waktu tersebut didasarkan atas SMA $100>$ SMA 200 . Metode pengambilan data dilakukan dengan mengunduh melalui database id.investing.com dan observasi untuk meneliti fenomena yang terjadi pada simbol-simbol di dalamnya. Jenis data yang diolah dalam penelitian ini berjenis data sekunder, yaitu data yang siap diolah peneliti tanpa perlu mengolah data mentahnya (Nur, 2015).

Berdasarkan jenisnya, penelitian ini termasuk ke dalam metode penelitian deskriptif kualitatif yang membahas tentang pergerakan harga saham UNVR di pasar bursa. Penelitian deskriptif kualitatif fokus terhadap suatu obyek dan interaksinya terhadap fenomena yang diteliti secara mendalam (Moleong, 2017), sehingga penelitian ini fokus kepada fenomena akibat interaksi Saham UNVR terhadap pasar yang ditinjau dengan indikator Simple Moving Average dan Stochastic Oscillator. Dengan pemaparan tersebut dapat dijelaskan adanya fakta atas sebuah fenomena yang terjadi. Sehingga dapat diteliti lebih lanjut terhadap efisiensi Entry dan Exit pada saham UNVR.

Kerangka fikir penelitian ini didasarkan oleh langkah-langkah penelitian guna 
mendapatkan hasil yang akurat. Adapun kerangka fikir penelitian adalah sebagai berikut:

Bagan 1. Kerangka Fikir Penelitian

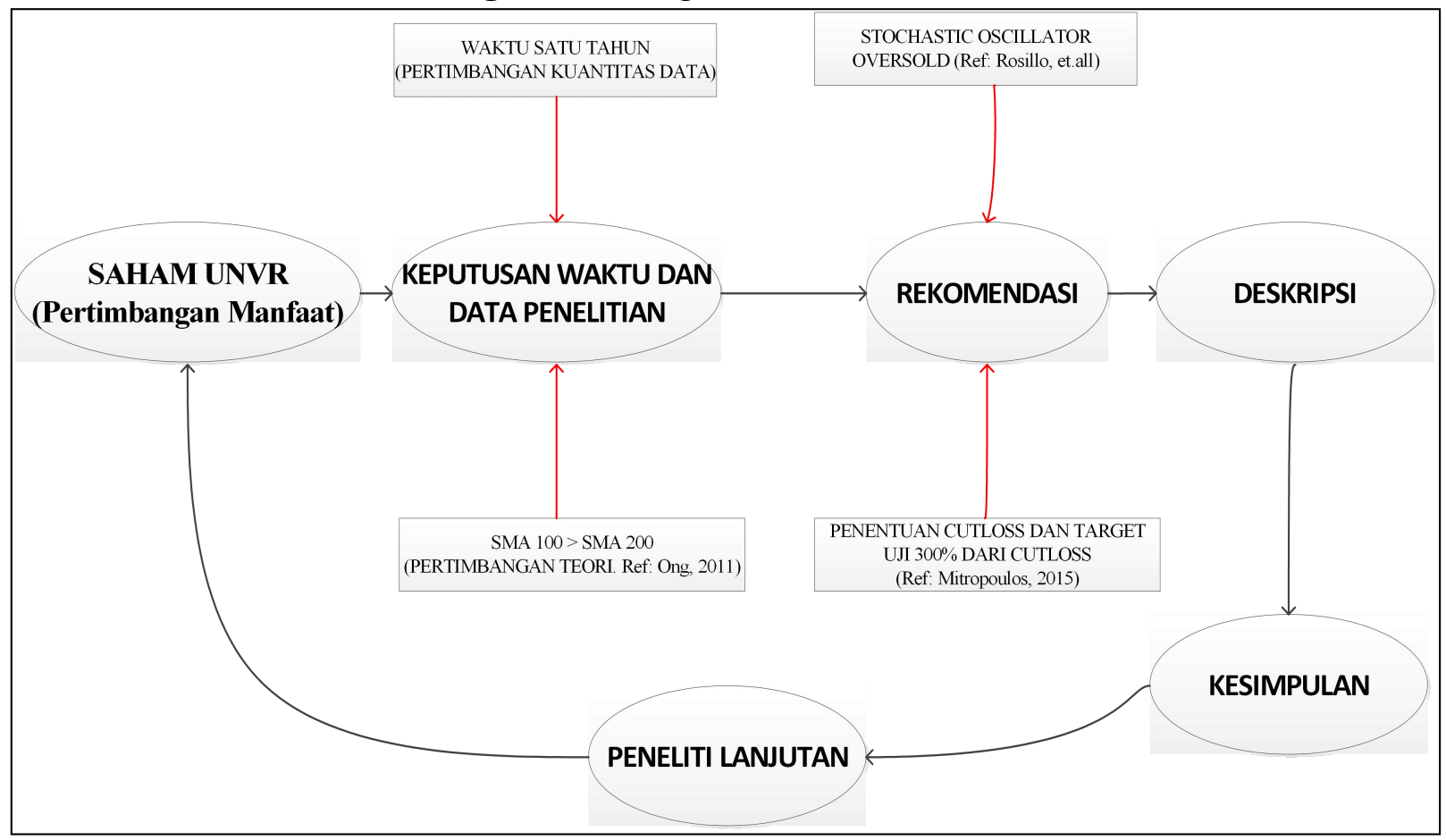

Sumber: Peneliti, 2019

Kerangka fikir dimulai dari pemilihan saham UNVR karena adanya pertimbangan manfaat obyek penelitian yaitu Traders. Guna memfokuskan penelitian ini dilakukan pembatasan waktu berdasarkan dua pertimbangan, yaitu waktu satu tahun (12 bulan) dengan pertimbangan kuantitas data yang tersedia dan keterbatasan waktu penelitian.

Dari 12 bulan waktu open market, ternyata tidak dapat ditentukan secara lepas. Berdasarkan teori Ong (2011), entry dan exit yang efektif didasarkan atas pertimbangan SMA $100>$ SMA 200. Dari kedua pertimbangan tersebut dihasilkan pengambilan data penelitian yaitu mulai dari tanggal 2 Juni 2017 sampai dengan 21 Juni 2018 dan terdapat kelebihan waktu total selama 19 hari.

Setelah waktu telah ditentukan, dapat dilakukan pelaksanaan analisis rekomendasi. Analisis rekomendasi dilakukan dengan metode observasi terhadap indikator Stocastic Oscillator yang masuk area over sold dan membentuk golden cross. Sedangkan penentuan entry ideal bukan saat terjadinya golden cross namun candle setelahnya dengan ciri khas Close $_{t} \geq$ Hight $_{n-t}$, dimana $\mathrm{n}$ merupakan harga tertinggi candle stick sebelumnya dan $\mathrm{t}$ merupakan waktu penutupan candle stick sebelumnya (Rosillo dkk., 2013).

Apabila telah diketahui titik-titik golden cross dan candle Close $_{t} \geq$ Hight $_{n-t}$ kemudian dilakukan penentuan target dengan analisis hitung sederhana berdasarkan penelitian yang telah dilakukan oleh Mitropoulos, et.al (2015) yaitu $\mathrm{T}=\mathrm{E}+\{(\mathrm{E}-\mathrm{Cl}) \times 300 \%\}$. Adapun $\mathrm{T}$ merupakan target exit; E merupakan entry yang diinginkan oleh Trader dengan bantuan Stochastic Oscillator dan candle Close $_{t} \geq$ Hight $_{n-t} ; \mathrm{Cl}$ adalah Cutloss yang ditentukan berdasarkan nilai low dari candlestick Close $_{n-t}$. Setelah ditentukan target barulah dapat dituliskan rekomendasi terhadap waktu-waktu exit yang efektif serta dapat dideskripsikan untuk menarik sebuah kesimpulan apakah metode Ong (2011) efektif digunakan dalam 
menentukan entry dan exit ideal untuk mendapatkan profit maksimal dalam sistem trading.

Penelitian kualitatif deskriptif ini menggunakan empat instrumen yaitu: (1) candlestick graph; (2) trendline; (3) Simple Moving Average (SMA); dan (4) Stochastic Oscillator. Instrumen ini diambil sesuai dengan fungsinya yaitu sebagai alat untuk mengumpulkan semua data penting dalam penelitian kemudian diolah menjadi sebuah informasi sesuai dengan metode penelitian yang digunakan (Noeraini \& Sugiyono, 2016).

Alat analisia data yang digunakan dalam penelitian ini adalah Analisis Konten. Analisis konten adalah alat analisis yang biasa digunakan dalam penelitian deskriptif kualitatif berfungsi untuk menganalisis informasi tertulis maupun tidak tertulis dalam media masa. Informasi tersebut dapat berupa simbol, lambang, suara atau data yang kemudian dilakukan upaya interpretasi dengan langkah-langkah coding sesuai dengan peraturan dan prosesnya (Zuchdi, 1993).

Dalam penelitian ini konten informasi banyak berupa simbol-simbol dan gejalanya yang terjadi. Simbol-simbol yang penting untuk dianalisi adalah candlestick, garis tren, indikator grafik, serta angka yang menunjukkan harga saham dan kekuatan indikator yang memiliki arti dalam setiap bentuk dan cekungannya terhadap kondisi pasar. Kemudian penting pula untuk menentukan efektifitas tindakan entry atau exit dalam upaya taking profit oleh para Traders. Sedangkan langkah-langkah coding dan peraturan serta prosesnya mengacu pada referensi yang kredibel untuk menjelaskan makna dari gejala yang terbentuk. Adapun referensi utama yang digunakan adalah Teori Dow dalam Ong (2011).

Upaya penyempurnaan dari analisis konten haruslah ada upaya interpretasi, upaya interpretasi dalam penelitian ini menggunakan analisis data model Miles and Hubberman. Miles and Hubberman menekankan pandangan positivisme dengan melihat adanya sebab dan akibat yang ada (Miles \& Huberman, 2014). Sesuai dengan Teori Dow dalam Ong (2011) yang menyatakan bahwa pergerakan pasar saat ini akan menyebabkan kondisi pasar masa depan dan juga pernyataannya yang menyatakan pergerakan pasar saat ini adalah perulangan sejarah masa lalu mendasari penggunaan teknik analisa data Miles and Hubberman.

Teknik analisa data Miles and Hubberman terdiri atas tiga komponen utama (Miles \& Huberman, 2014), yaitu: (1) reduksi data; (2) paparan data; dan (3) verivikasi data. Reduksi data dilakukan dengan mengambil data yang penting dan digunakan saja termasuk di dalamnya membatasi waktu berdasarkan SMA $100>$ SMA 200; paparan data dilakukan dengan menganalisis trendline dan titik entry serta exit menggunakan Stochastic Oscillator; sedangkan verivikasi data adalah langkah akhir yaitu menyimpulkan hasil berupa titik-titik entry dan exit yang menunjukkan poin-poin harga untuk mendapatkan profit maksimal.

\section{HASIL DAN PEMBAHASAN}

\section{Gambaran Umum Saham UNVR}

PT. Unilever, tbk. (dengan kode emiten UNVR) merupakan perusahaan yang memiliki saham blue chip. Saham ini memiliki kekuatan fundamental yang sangat baik sehingga mampu memberikan deviden yang besar kepada para investornya. Di pasar bursa UNVR terbilang cukup dibidik para Traders karena fluktuasinya yang cukup besar, sehingga banyak Trader murni maupun Trader as investors yang bergelut pada saham UNVR.

UNVR memiliki pergerakan yang cukup signifikan selama tahun 2017 hingga tahun 2018. Harga tertinggi emiten ini senilai Rp 58.100 per lembar atau Rp 5.810.000 per lot yang pernah tersentuh pada tanggal 2 Januari 2018. Sedangkan harga terendah mencapai Rp 38.800 per lembar atau Rp 3.880.000 per lot yang pernah tersentuh tanggal 3 Januari 2017. 
Pergerakan UNVR yang ideal untuk maximum taking profit merujuk kepada indikator Simple Moving Average (SMA), dengan ketentuan SMA 100 > SMA 200, hal itu terjadi pada tanggal 2 Juni 2017 sampai dengan 21 Juni 2018. Bila ditarik rentang waktu pergerakan idealnya terjadi selama 1 tahun 19 hari.

\section{Rekomendasi Menggunakan Indikator Stochastic Oscillator}

Langkah kedua adalah memberikan rekomendasi waktu yang tepat untuk menganalisis entry dan exit menggunakan indikator Stochastic Oscillator. Setelah dilakukan screening terhadap golden cross yang terjadi selama satu tahun lebih dalam waktu open market didapatkan sembilan waktu rekomendasi.

Kesembilan waktu rekomendasi tersebut adalah tanggal: (1) 7 Agustus 2017; (2) 29 September 2017; (3) 12 Oktober 2017; (4) 15 Nopember 2017; (5) 8 Maret 2018; (6) 14 Maret 2018; (7) 26 April 2018; (8) 4 Mei 2018; dan (9) 4 Juni 2018. Dapat dideskripsikan juga adanya jarak indikator zero overshold pada Stochastic Oscillator pada tanggal 16 Nopember 2017 s.d 7 Maret 2018, waktu yang panjang ini dikarenakan adanya strong bullish pada UNVR.

Pada jeda waktu ini pula terjadi the top of price UNVR pada rentang waktu penelitian, yaitu terjadi pada tanggal 2 Januari 2018 dengan rincian harga sebagai berikut: Open (harga pembukaan) senilai Rp 56.175; High (harga tertinggi) Rp 58.100; Low (harga terendah) Rp 55.000; Close (harga penutupan) Rp 55.875. Walaupun UNVR saat itu ditutup dengan harga lebih rendah dari pembukaannya (bearish), namun momen tersebut mencetak harga tertinggi dalam kurun waktu penelitian sekaligus menjadi harga titik balik sebelum terjadi bearish reversal.

\section{Penentuan Cut Loss (Cl) dan Target}

Gambar 2. Penentuan Rekomendasi Target Entry dan Exit UNVR

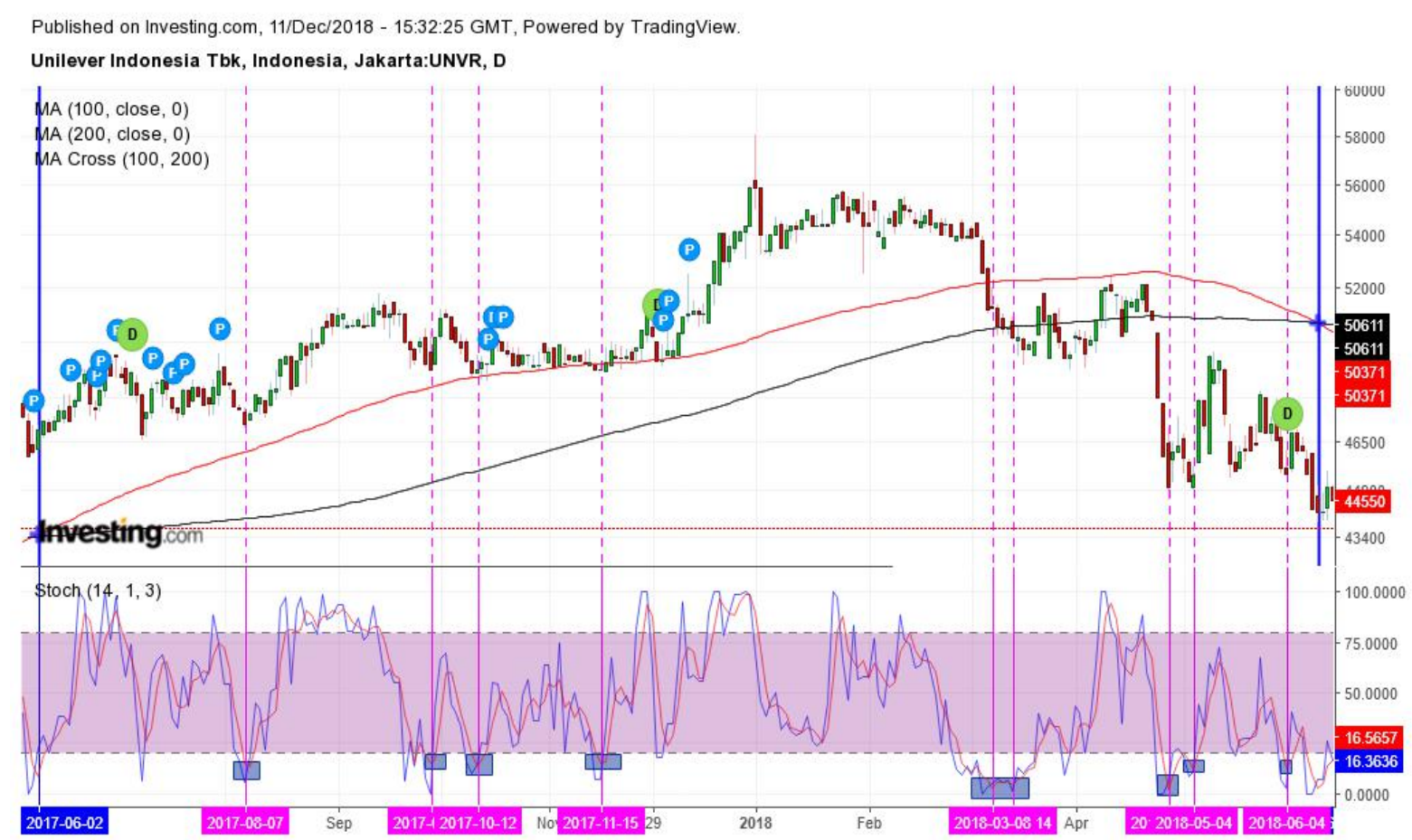

Sumber: Peneliti, 2019 
Terlepas dari penting atau tidaknya $\mathrm{Cl}$ dalam dunia trading begitu pula terlepas dari boleh atau tidak dalam penerapannya sesuai dengan hukum Syariat, penelitian ini tetap mewajibkan penggunaan teknik penentuan $\mathrm{Cl}$ untuk menentukan target exit price. Dari hasil rekomendasi Stochastic Oscillator tanggal 7 Agustus 2017 candle stick yang layak untuk menentukan rekomendasi target tertanggal 9 Agustus 2017. Dengan Cl seharga Rp 46.928 dan E seharga Rp 48.000, maka target ideal sebesar Rp 51.216 yang terjadi tanggal 13 September 2017 dengan harga tertingginya mencapai Rp 51.400. Artinya jarak antara golden cros yang ditunjukkan Stochastic Oscillator dengan target terjadi selama 25 hari open market.

Rekomendasi Stochastic Oscillator tanggal 29 September 2017, candle stick yang dapat dijadikan rekomendasi target terjadi pada tanggal 3 Oktober 2017. Cl seharga Rp 49.600 dan

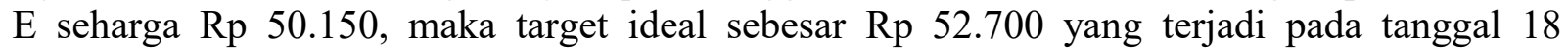
Desember 2018 dengan harga tertinggi Rp 52.975. Artinya target dapat dicapai selama hampir tiga bulan open market.

Rekomendasi Stochastic Oscillator tanggal 12 Oktober 2017, candle stick yang dapat dijadikan rekomendasi target terjadi pada tanggal 17 Oktober 2017. Cl seharga Rp 48.875 dan E seharga $\mathrm{Rp}$ 49.200, target ideal sebesar Rp 50.175. Target dapat dicapai pada tanggal 18 Oktober 2017, sehingga hanya membutuhkan waktu 24 jam untuk mencapai target.

Rekomendasi Stochastic Oscillator pada tanggal 15 November 2017, candle stick yang dapat dijadikan rujukan terjadi pada tanggal 16 November 2017. Cl seharga Rp 48.950 dan E seharga Rp 49.350, target ideal sebesar Rp 50.550. Target ini dapat dicapai pada tanggal 28 November 2017 dengan harga tertinggi Rp 51.000. Sehingga dibutuhkan waktu sembilan hari open market untuk mendapatkan profit maksimal dari entry yang dipatok.

Rekomendasi Stochastic Oscillator tanggal 8 Maret 2018, candle stick yang dapat dijadikan rekomendasi target terjadi pada tanggal 21 Maret 2018, Cl seharga Rp 50.200 dan E seharga Rp 51.175, target ideal sebesar Rp 54.100. Target ini belum terpenuhi hingga waktu batasan penelitian terlewati.

Rekomendasi Stochastic Oscillator pada tanggal 14 Maret 2018, candle stick yang dapat dijadikan rekomendasi terjadi pada tanggal 21 Maret 2018. Cl seharga Rp 50.050 dan E seharga Rp 50.750, target ideal sebesar Rp 52.850. Target ini belum terpenuhi hingga watu batasan penelitian terlewati.

\section{PENUTUP}

Waktu ideal bagi para Trader untuk melakukan investasi (trading invest) yang paling baik antara tahun 2017 s.d 2018, tepatnya mulai dari 2 Juni 2017 s.d 21 Juni 2018. dengan menghasilkan sembilan rekomendasi entry dan exit, dari kesembilan rekomendasi terdapat delapan rekomendasi tercapai target exit dan dua rekomendasi belum tercapai.

Disarankan kepada peneliti selanjutnya untuk melakukan penelitian lanjutan khususnya dalam membuktikan dua target exit yang telah direkomendasikan namun belum tersentuh hingga lewatnya batasan waktu penelitian. Disarankan pula untuk melakukan penelitian lebih mendalam yang fokus membuktikan keefektifan SMA 100, SMA 200, dan Stochastic Oscillator dalam menentukan target exit sesuai dengan entry yang telah direkomendasikan dalam penelitian ini terhadap Traders dengan masing-masing tipenya. Penentuan tipe didasarkan atas waktu tradingnya apakah short term trading, medium term trading, atau long term trading (trading as investor).

Direkomendasikan kepada peneliti selanjutnya, apaila akan membuktikan dua target yang belum tersentuh, dapat meluaskan waktu penelitian selama dua tahun atau menggesernya 
dari titik-titik rekomendasi yang telah dibuktikan dalam penelitian ini. Sedangkan untuk membuktikan keefektifan SMA 100, SMA 200, dan Stochastic Oscillator dalam menentukan target exit perlu dilakukan dengan metode analisis data secara komparatif dan deskriptif. Komparatif berfungsi untuk membandingkan kesesuaian target pada ketiga jenis Trader sedangkan deskriptif berfungsi untuk memaparkan hasil dari keefektifan tersebut sekaligus memaparkan gerak SMA 100, SMA 200, dan Stochastic Oscillator dalam merekomendasikan titik-titik yang dijadikan perbadingannya.

\section{REFERENSI}

Anonim. (2018). Sejarah Kami, diakses pada tanggal 18 September 2018, dari https:/www.unilever.co.id/about/who-we-are/our-history/

Bessembinder, H., \& Chan, K. 1998. Market Efficiency and the Returns to Technical Analysis. Financial Management, 27(2), 5-17.

Burns, S., \& Burns, H. 2015. Incredible Signals That Will Make You Money in the Stock Market. LLC: Stolly Media.

Chandra, A. A. (2017). 35 Tahun Melantai di BEI, Saham Unilever Dari Rp 3.000 Jadi Rp 39.000 diakses pada tanggal 18 September 2018, dari https://finance.detik.com/bursadan-valas/d-3392953/35-tahun-melantai-di-bei-saham-unilever-dari-rp-3000-jadi-rp39000

Droke, C. 2001. Moving Average Simplified. USA: Marketplace Book.

Gencay, R., \& Stengos, T. 1998. Moving average rules, volume and the predictability of security returns with feedforward networks. Journal of Forecasting, 17(5-6), 401-414.

id.investing.com. (2018). Grafik Live-Investing.com, diakses pada tanggal 18 September 2018, dari https://id.investing.com/charts/live-charts

Mangkulo, H. A. 2014. Analisa Teknikal Saham dengan Chart Nexus. Jakarta: Elex Media Komputindo.

Miles, M. B., \& Huberman, A. M. 2014. Analisis Data Penelitian Kualitatif: Pemahaman Filosofis dan Metodologis kea rah Penguasaan Model Aplikasi. Jakarta: Rajawali Pers.

Mitropoulos, P., Talias, M. A., \& Mitropoulos, I. 2015. Combining stochastic DEA with Bayesian analysis to obtain statistical properties of the efficiency scores: An application to Greek public hospitals. European Journal of Operational Research, 243(1), 302-311.

Moleong, L., J. 2017. Metodologi Penelitian Kualitatif(Edisi Revisi). Jakarta: Roesda Karya.

Murphy, J. . 1999. Technical Analysis of The Financial Markates: A Comprehensive Guide to Trading Methods and Applications. New York: New York Institute of Finance.

Noeraini, I. A., \& Sugiyono, S. 2016. Pengaruh Tingkat Kepercayaan, Kualitas Pelayanan, Dan Harga Terhadap Kepuasan Pelanggan JNE Surabaya. Jurnal Ilmu \& Riset Manajemen, 5(5).

Noviani, A. (2018). Kuartal I/2018, Unilever Indonesia (UNVR) Bukukan Laba Rp1,84 Triliun - Market Bisnis.com, diakses pada tanggal 18 September 2018, dari http://market.bisnis.com/read/20180424/192/788019/kuartal-i2018-unilever-indonesiaunvr-bukukan-laba-rp184-triliun

Nur, M. (2015). Kinerja Badan Layanan Umum Daerah (Blud) Berdasarkan Balanced Scorecard Di Rumah Sakit Umum (Rsu) Tgk Chiek Ditiro Sigli Kabupaten Pidie, Tesis, dipublikasikan. Medan: Fakultas Ilmu Kesehatan Masyarakat Universitas Sumatera Utara.

Ong Edianto. 2011. Technical Analysis for Mega Profit. Jakarta: Gramedia Pustaka Tama. 
Rosillo, R., de la Fuente, D., \& Brugos, J. A. L. (2013). Technical analysis and the Spanish stock exchange: testing the RSI, MACD, momentum and stochastic rules using Spanish market companies. Applied Economics, 45(12), 1541-1550.

Shen, L., \& Loh, H. T. (2004). Applying rough sets to market timing decisions. Data mining for financial decision making, 37(4), 583-597.

Syamsir M. 2004. Solusi Investasi di Bursa Saham Indonesia: Pendekatan Analisis Teknikal Melalui Studi Kasus Riil dengan Dilengkapi Formulasi Metastock. Jakarta: Elex Media Komputindo.

Tjiptono, D., \& Fakhrudin, H. M. 2012. Pasar Modal Indonesia (3 ed.). Jakarta: Salemba Empat.

Vibby, S. 2008. Jual Saham Anda Lebih Mahal. Jakarta: Vibby Publishing.

Wira, D. 2014. Analisis Teknikal untuk Profit Maksimal (2 ed.). Jakarta: Exceed.

Zhu, Y., \& Zhou, G. 2009. Technical analysis: An asset allocation perspective on the use of moving averages. Journal of Financial Economics, 92(3), 519-544.

Zuchdi, D. 1993. Panduan Analisis Konten: Seri Metodologi Penelitian. Yogyakarta: IKIP Yogyakarta. 